Article

\title{
Additive Effect of a Combination of Artocarpus lakoocha and Glycyrrhiza glabra Extracts on Tyrosinase Inhibition in Melanoma B16 Cells
}

\author{
Tasanee Panichakul ${ }^{1, *}$, Teerapat Rodboon ${ }^{2}$, Prasit Suwannalert ${ }^{2}$, Chanchai Tripetch ${ }^{1}$, \\ Rittipun Rungruang ${ }^{1}$, Nattaporn Boohuad ${ }^{1}$ and Piyawan Youdee ${ }^{3}$ \\ 1 Department of Cosmetic Science, Faculty of Science and Technology, Suan Dusit University, \\ 228-228/1-3 Sirindhorn Rd. Bangplad, Bangkok 10700, Thailand; chanchai_tre@dusit.ac.th (C.T.); \\ rittipun_run@dusit.ac.th (R.R.); nattaporn_boo@dusit.ac.th (N.B.) \\ 2 Department of Pathobiology, Faculty of Science, Mahidol University, 272 Rama VI Rd., Ratchathewi District, \\ Bangkok 10400, Thailand; teerapat.rob@student.mahidol.ac.th (T.R.); prasit.suw@mahidol.ac.th (P.S.) \\ 3 School of Culinary Arts, Suan Dusit University, 228-228/1-3 Sirindhorn Rd. Bangplad, \\ Bangkok 10700, Thailand; piyawan_you@dusit.ac.th \\ * Correspondence: tasanee_pan@dusit.ac.th
}

Received: 19 September 2020; Accepted: 11 October 2020; Published: 14 October 2020

\begin{abstract}
Artocarpus lakoocha (Al) and Glycyrrhiza glabra (Gg) extracts have been reported to show tyrosinase inhibitory activity and melanin pigment reduction. This is the first study to assess the combination of $\mathrm{Al}$ and $\mathrm{Gg}$ extracts in enhancing inhibition of tyrosinase and reduction of melanin pigments. $\mathrm{Al}$ and $\mathrm{Gg}$ extracted by maceration in $70 \%$ and $95 \%$ ethanol were analyzed for oxyresveratrol and glabridin using Ultra High Performance Liquid Chromatography. Extracts of $\mathrm{Al}$ and Gg singly and combinations of Al95 and Gg95 were tested for cytotoxicity, tyrosinase inhibitory activity, and reduction of melanin pigments in melanoma B16 cells. A195 had higher antioxidant, tyrosinase inhibitory activity and reduced more melanin pigments in B16 cells compared to Al70, and exhibited higher levels of oxyresveratrol. Gg95 inhibited oxidative stress and mushroom tyrosinase better than Gg70, and exhibited higher levels of glabridin. Combinations of A195 and Gg95 at various ratios (concentration of $0.1 \mathrm{mg} / \mathrm{mL}$ ) were not cytotoxic to B16 cells. Interestingly, Al95 and Gg95 combined at a ratio 9:1 reduced melanin pigment up to $53 \%$ in B16 cells. This combination of A195 and Gg95 extracts exhibited the additive effect of reducing melanin pigments by suppressing the expression of microphthalmia-associated transcription factor (MITF), tyrosinase (TYR) and tyrosinase-related protein-2 (TRP-2) in B16 cells. The combination of Al and Gg extracts could be developed as skin care products for hyperpigmentation treatment.
\end{abstract}

Keywords: Artocarpus lakoocha; Glycyrrhiza glabra; oxyresveratrol; glabridin; tyrosinase; melanin

\section{Introduction}

Human skin color is primarily determined by the content of melanin, a pigment that is produced by dermal melanocytes through melanogenesis. Melanin plays an important role in photoprotection and preventing skin cancer caused by UV radiation [1]. However, hyperpigmentation disorders like melasma and actinic lichen planus are considered dermatological problems. Controlling melanogenesis is important for preventing aberrant pigmentation. Melanogenesis is regulated by tyrosinase (TYR), tyrosinase-related protein-1 and 2 (TRP-1 and TRP-2), and the microphthalmia-associated transcription factor (MITF) [2,3]. TYR is the pivotal regulator of melanin production, catalyzing the hydroxylation 
of tyrosine to form L-3, 4-dihydroxyphenylalanine (L-DOPA), followed by oxidation of L-DOPA to produce DOPA-quinone [4]. TRP-1 and TRP-2 function in the biosynthesis of melanin downstream of TYR. TRP-2 catalyzes the production of 5,6-dihydroxyindole-2-carboxylic acid (DHICA) from dopa-chrome, and TRP-1 oxidizes DHICA to produce indole-5,6-quinone carboxylic acid, ultimately resulting in melanin formation [5-7]. The tyrosinase family genes, including TYR, TRP-1, and TRP-2 are regulated by MITF [8-10]. MITF strongly regulates TYR gene expression and this transcription factor plays a key role in melanogenesis [5,11]. Inhibition of melanin synthesis, through disruption of melanogenesis, could improve or prevent hyperpigmentation disorders. Numerous substances have been reported as tyrosinase inhibitors and mediate their effects either as competitive and noncompetitive inhibitors [12]. Tyrosinase inhibitors include L-ascorbic acid [13-15], kojic acid [16,17], ellagic acid [18], tranexamic acid [19-21], arbutin [22], and hydroquinone [23,24]. These compounds have been proposed as skin-whitening agents for the topical treatment of hyperpigmentation disorders. However, several side effects from these skin-whitening agents have been reported. 1,4-dihydroquinone can cause reversible inhibition of cellular metabolism, which is attributed to induce melanocyte cytotoxicity and mutation [25]. In addition, kojic acid can trigger contact dermatitis [26] and has carcinogenic potential $[27,28]$. Therefore, there is considerable interest in finding alternative, herbal depigmenting agents.

Artocarpus lakoocha (Al) Roxb. (Moraceae), also known as Artocarpus lacucha, is a tropical tree found in South and Southeast Asia, including Southern China, India, Sri Lanka, Myanmar, Thailand, Malaysia, and Indonesia [29]. In Thailand, Ma-Haad is the common name for $\mathrm{Al}$ and the aqueous extract from this plant, Puag-Haad, has been traditionally used as an antihelmintic drug for treatment of tapeworm infections [30,31]. Ethanolic extracts of $\mathrm{Al}$ heartwood have shown potential antioxidant and tyrosinase inhibitory activities [32,33]. The active components in the Al heartwood extract with tyrosinase inhibitory activity are oxyresveratrol and resveratrol, which have potential use as skin whitening agents $[31,34,35]$. Hydroglycolic extracts of $\mathrm{Al}$ heartwood also exhibit antioxidant and in vitro tyrosinase inhibitory activities, as well as in vivo melanin-reducing effects in human volunteers. These reports indicate that $\mathrm{Al}$ extracts may have potential for skin-whitening agents [29,34].

Glycyrrhiza glabra $(\mathrm{Gg})$ from the family Fabaceae, is commonly known as liquorice, is cultivated in several regions, including China, Turkey, Syria, Italy, Pakistan, and Uzbekistan [36,37]. Liquorice is widely utilized as a natural flavor extract in food and pharmaceutical products. In addition, it has been traditionally proposed for the treatment of upper and lower respiratory diseases, skin disorder, diabetes, gastrointestinal ulcers, stomach ache, and cardiovascular diseases [38]. The hydrophobic fraction from extracts of $\mathrm{Gg}$ contained flavonoids and exhibited inhibitory effects on melanogenesis $[39,40]$ and extracts from $\mathrm{Gg}$ have been used as a depigmentation agent in cosmetic products [41]. Glabridin, a polyphenolic flavonoid compound found in Gg extract, has been reported to inhibit the tyrosinase activity of melanocytes [42] and may be the active component of Gg extracts.

Loss of effectiveness and side effects, like skin irritation, may appear when using a mono-extract as a long-term treatment. In this study, the combination of $\mathrm{Al}$ and $\mathrm{Gg}$ extracts was investigated for cellular cytotoxicity, tyrosinase inhibitory activities, and reduction of melanin contents in melanoma B16 cells. The expression of MITF, TYR, TRP-1, and TRP-2 in B16 cells was also evaluated. Enhancement of tyrosinase inhibitory activity and reduction of melanin content using a combination of $\mathrm{Al}$ and $\mathrm{Gg}$ extracts appears to be an alternative approach for treatment of hyperpigmentation disorders. This combination of $\mathrm{Al}$ and $\mathrm{Gg}$ extracts also has potential use as a whitening agent in skin care products.

\section{Results}

\subsection{Chemical Profiles, Total Phenolic, Flavonoid Contents Antioxidant and Tyrosinase Inhibitory Activities in} Extracts of A. lakoocha and G. glabra

The total phenolic and flavonoid contents of A. lakoocha (Al) and G. glabra $(\mathrm{Gg})$ extracts prepared using either $70 \%$ or $95 \%$ ethanol (Al70, A195, Gg70 and Gg95) were determined. Results showed that $\mathrm{Al}$ extracts had higher levels of total phenolic content than Gg extracts. The total phenolic content of Al95 
was the highest with $398.44 \pm 20.47 \mathrm{mg}$ gallic acid equivalent (GAE) equivalents/g extract. The Al70, Gg70 and Gg95 extracts had $127.99 \pm 5.22,90.76 \pm 11.23$ and $215.07 \pm 24.37 \mathrm{mg}$ GAE equivalent/g, respectively. The total flavonoid contents of Al70, Al95, Gg70 and Gg95 were $2.05 \pm 0.09,8.79 \pm 0.40$, $5.87 \pm 0.56$ and $9.20 \pm 0.84 \mathrm{mg}$ quercetin equivalent $(\mathrm{QE})$ equivalent/g extract, respectively. This analysis indicated that the flavonoid contents from the $\mathrm{Gg}$ extracts were higher than those in the $\mathrm{Al}$ extracts. Analysis of Al70, A195, Gg70 and Gg95 extracts by Ultra High Performance Liquid Chromatography (UHPLC) revealed the presence of several chemical constituents (Figure 1). The chemical compounds in Al70 and Al95 extracts included gallic acid (0.56 min), oxyresveratrol (2.12 $\mathrm{min})$ and resveratrol ( $3.75 \mathrm{~min}$ ). One prominent peak for oxyresveratrol was found in both Al70 and Al95 extracts (Figure 1a). The concentrations of oxyresveratrol were $113.10 \pm 0.48$ and $149.58 \pm 0.43 \mathrm{mg} / \mathrm{g}$ of extract for Al70 and A195 extracts, respectively. Gallic acid and resveratrol were also found at low concentrations in Al70 and Al95 extracts. As shown in Figure 1b, major chemical compounds in Gg70 and Gg95 extracts included gallic acid $(0.56 \mathrm{~min})$ and glabridin $(8.84 \mathrm{~min})$. The concentrations of glabridin were $5.56 \pm 0.11$ and $12.48 \pm 0.48 \mathrm{mg} / \mathrm{g}$ of extract from Gg70 and Gg95 extracts, respectively. Glabridin was the major peak found in both Gg70 and Gg95 with gallic acid present at low levels in Gg extracts.

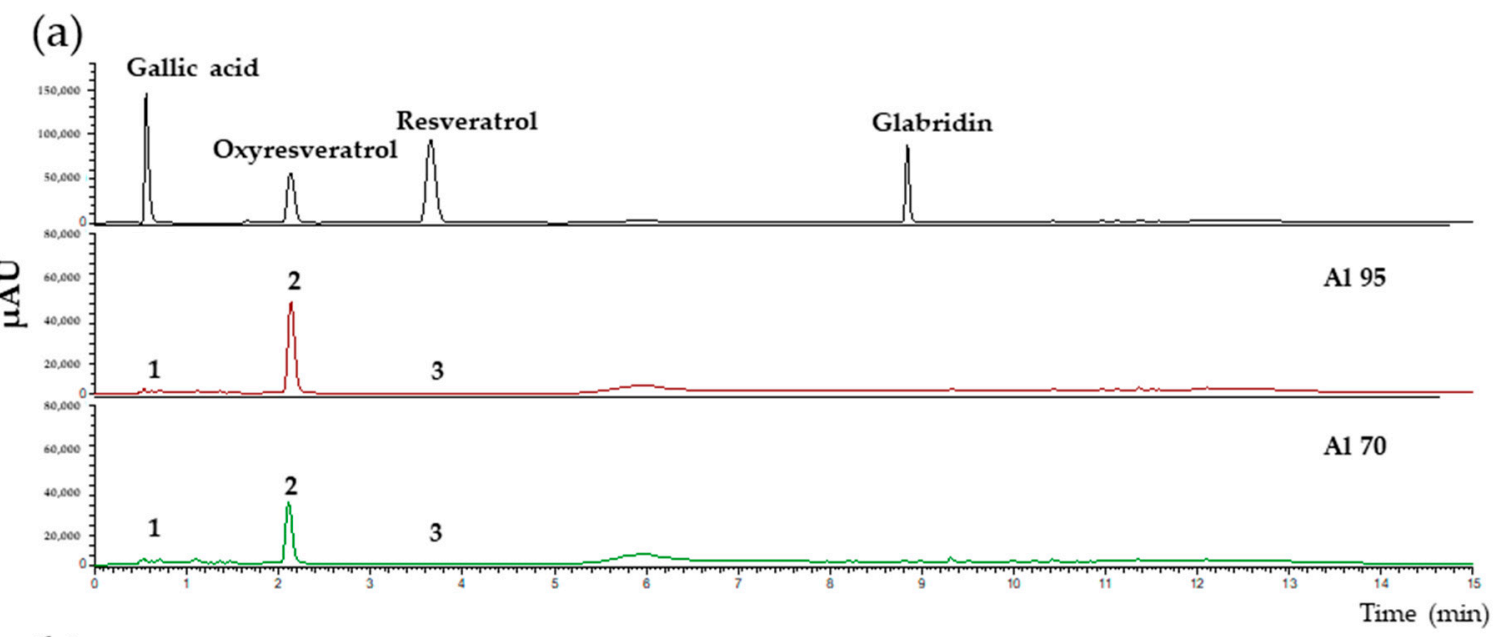

(b)

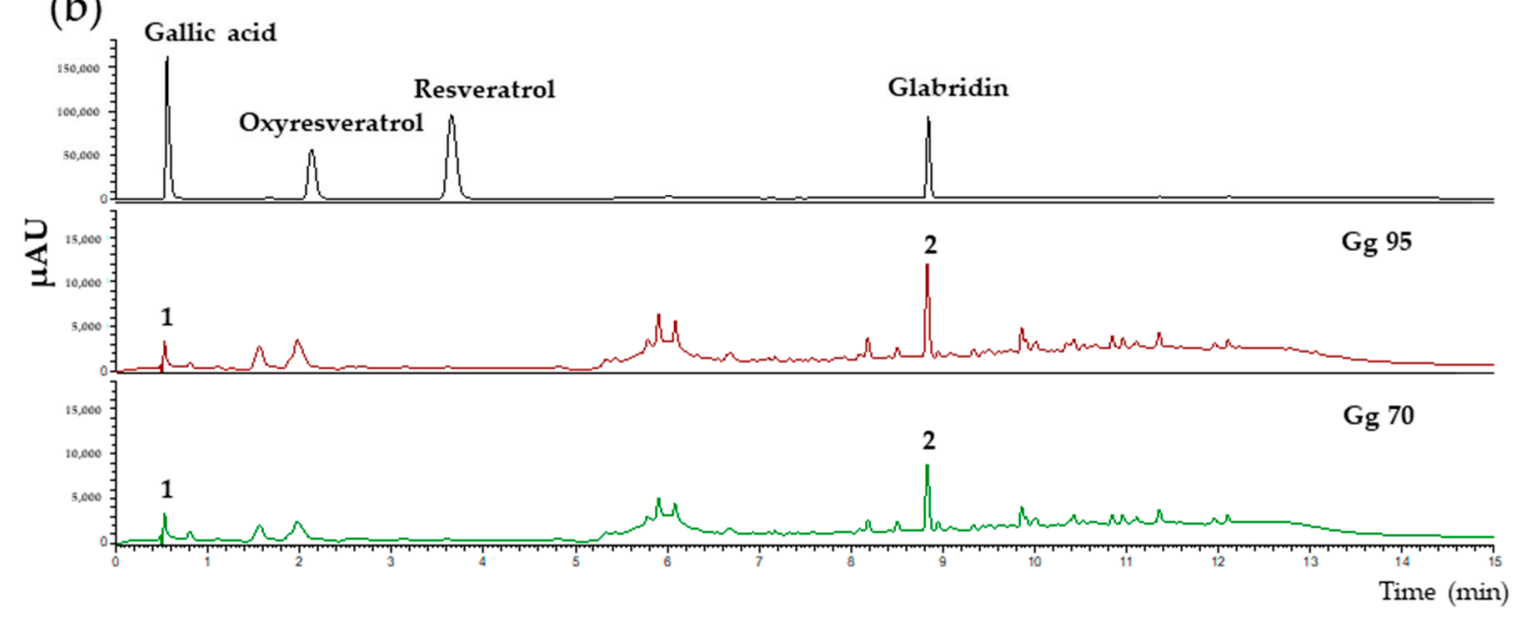

Figure 1. Chromatograms of A. lakoocha (Al) and G. glabra (Gg) extracts using $70 \%$ and $95 \%$ ethanol. Ultra High Performance Liquid Chromatography (UHPLC) analysis with detection at a wavelength of $280 \mathrm{~nm}$. (a) Standards (gallic acid, oxyresveratrol, resveratrol and glabridin) and the chromatograms from Al70 and Al95 extracts show gallic acid (1), oxyresveratrol (2) and resveratrol (3); (b) standards (gallic acid, oxyresveratrol, resveratrol and glabridin) and the chromatograms of Gg70 and Gg95 extracts showing gallic acid (1) and glabridin (2). 
The possible inhibitory effects of $\mathrm{Al}$ and $\mathrm{Gg}$ extracts on mushroom tyrosinase were analyzed. The results are presented as the concentration that inhibited $50 \%$ of the mushroom tyrosinase activity $\left(\mathrm{IC}_{50}\right)$ (Table 1). Al70, Al95, Gg70 and Gg95 extracts inhibited mushroom tyrosinase activity with $\mathrm{IC}_{50}$ values of $0.028,0.017,0.114$ and $0.074 \mathrm{mg} / \mathrm{mL}$, respectively. These values indicate that the $\mathrm{Al}$ and $\mathrm{Gg}$ extracts were more potent than kojic acid $\left(\mathrm{IC}_{50}=0.495 \mathrm{mg} / \mathrm{mL}\right.$ ) as tyrosinase inhibitors. Al had higher antioxidant and tyrosinase inhibitory activities than those of Gg extracts in Table 1. A195 exhibited the highest inhibitory effect on tyrosinase and this correlated with the total phenolic content and antioxidant activity of this extract. These results suggest that $\mathrm{Al}$ and $\mathrm{Gg}$ possessed anti-melanogenesis activity with a rank order of efficacy for $\mathrm{Al}$ and $\mathrm{Gg}$ to inhibit mushroom tyrosinase activity of A195 > $\mathrm{Al} 70>\mathrm{Gg} 95>\mathrm{Gg} 70$. The main chemical compounds found in crude extracts of A. lakoocha and G. glabra were oxyresveratrol and glabrindin, respectively.

Table 1. Total phenolic and flavonoid content, antioxidant activity, and mushroom tyrosinase inhibitory activity of $A$. lakoocha (Al) and G. glabra $(\mathrm{Gg})$.

\begin{tabular}{ccc}
\hline Extracts & $\begin{array}{c}\text { Tyrosinase Inhibitory Activity } \\
\left.\text { IC }_{\mathbf{5 0}} \text { (Mean } \pm \text { SD) } \mathbf{( m g} / \mathbf{m L}\right)\end{array}$ & $\begin{array}{c}\text { Radical Scavenging Activity } \\
\left.\left.\text { IC }_{\mathbf{5 0}} \text { (Mean } \pm \mathbf{S D}\right) \mathbf{( m g} / \mathbf{m L}\right)\end{array}$ \\
\hline Al70 & $0.028 \pm 0.0029$ & $0.081 \pm 0.027$ \\
A195 & $0.017 \pm 0.0024$ & $0.074 \pm 0.024$ \\
Gg70 & $0.114 \pm 0.0057$ & $0.365 \pm 0.171$ \\
Gg95 & $0.074 \pm 0.0011$ & $0.223 \pm 0.072$ \\
Kojic acid & $0.495 \pm 0.029$ & - \\
Ascorbic acid & - & $0.007 \pm 0.0008$
\end{tabular}

Data are means \pm SD from three independent experiments. $\left({ }^{1}\right)$ indicate significant difference at $p<0.01 . \mathrm{IC}_{50}$, the concentration of samples that inhibited $50 \%$ of tyrosinase inhibitory or antioxidant activities.

\subsection{Cytotoxicity of A. lakoocha and G. glabra Extracts in B16 Cells}

Cell viability of all extracts was analyzed using the 3-(4,5-dimethylthaizol-2-yl)-2,5diphenyltetrazolium bromide (MTT) assay to establish non-cytotoxic concentrations of the extracts from A. lakoocha and G. glabra (Figure 2). Survival with more than $95 \%$ of the B16 cells was used to determine the safety concentration of A. lakoocha and G. glabra extracts. The concentration of extracts that resulted in a cell viability of $98-99 \%$ was $0.1 \mathrm{mg} / \mathrm{mL}$ for Al70 and Al95 (Figure 2a) and $0.8 \mathrm{mg} / \mathrm{mL}$ for Gg70 and Gg95 (Figure 2b). These concentrations of Al and Gg extracts were considered safe and selected as the highest dose for use in analysis of their effects on cellular melanin content and tyrosinase activity. 

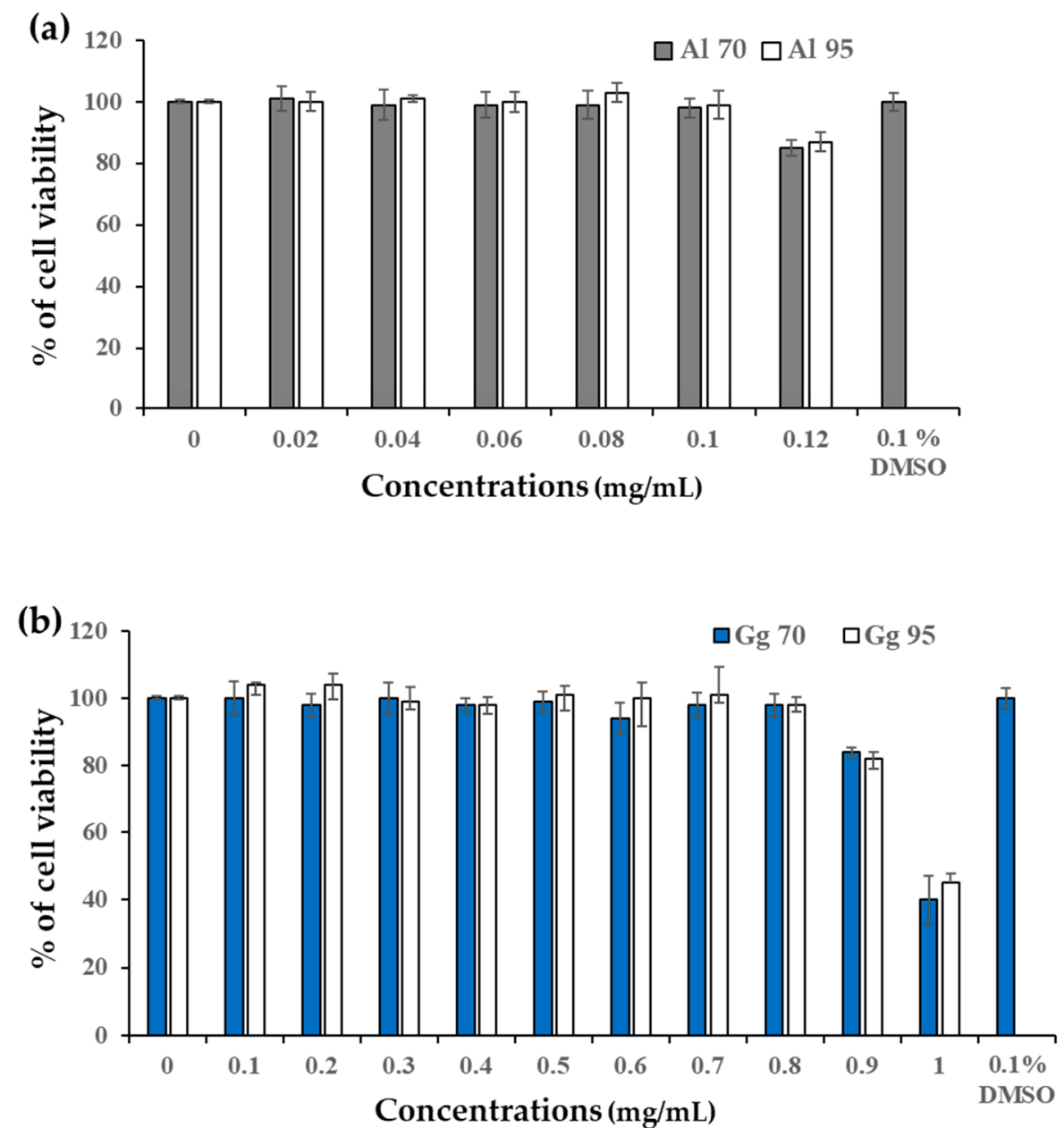

Figure 2. Viability of B16 cells exposed to A. lakoocha and G. glabra extracts. (a) A. lakoocha macerated in 70\% (Al70) and 95\% (A195) of ethanol; and (b) G. glabra macerated in 70\% (Gg70) and 95\% (Gg95) of ethanol. Percentages of cell viability means \pm SD from three independent experiments.

\subsection{A. lakoocha and G. glabra Extracts Decreased Cellular Melanin Content and Tyrosinase Activity}

The inhibitory effect of $\mathrm{Al}$ and $\mathrm{Gg}$ extracts on cellular melanin content and tyrosinase activity in B16 cells is illustrated in Figure 3. B16 cells were treated with non-cytotoxic concentrations of Al $(0.02-0.1 \mathrm{mg} / \mathrm{mL})$ and $\mathrm{Gg}(0.1-0.8 \mathrm{mg} / \mathrm{mL}) . \mathrm{Al}$ and $\mathrm{Gg}$ produced a dose-dependent decrease in the melanin content (Figure 3a,c). The inhibitory effects of A195 on melanin synthesis and tyrosinase activity were significantly higher than those of Al70 $(p<0.01)$. This difference was noted for at $\mathrm{Al}$ concentrations ranging from 0.06 to $0.1 \mathrm{mg} / \mathrm{mL}$. Al95 at a concentration of $0.1 \mathrm{mg} / \mathrm{mL}$ was able to reduce melanin content $39 \%$ (Figure $3 \mathrm{a}$ ) and tyrosinase activity by $34 \%$ (Figure $3 \mathrm{~b}$ ). In contrast, Gg70 and Gg95 extracts, at concentrations of 0.7 and $0.8 \mathrm{mg} / \mathrm{mL}$, decrease melanin content by $10 \%$ to $17 \%$ (Figure $3 \mathrm{c}$ ) and tyrosinase activity by $10 \%$ to $19 \%$ (Figure 3d). No significant differences were found in the effects of Gg70 and Gg95 $(p<0.01)$ extracts. These results indicate that $\mathrm{Al}$ reduced the cellular accumulation of melanin pigment by inhibiting tyrosinase activity. However, a higher concentration of $\mathrm{Gg}$ resulted in a more limited effect on inhibition of tyrosinase activity as well as cellular content of melanin pigment. 

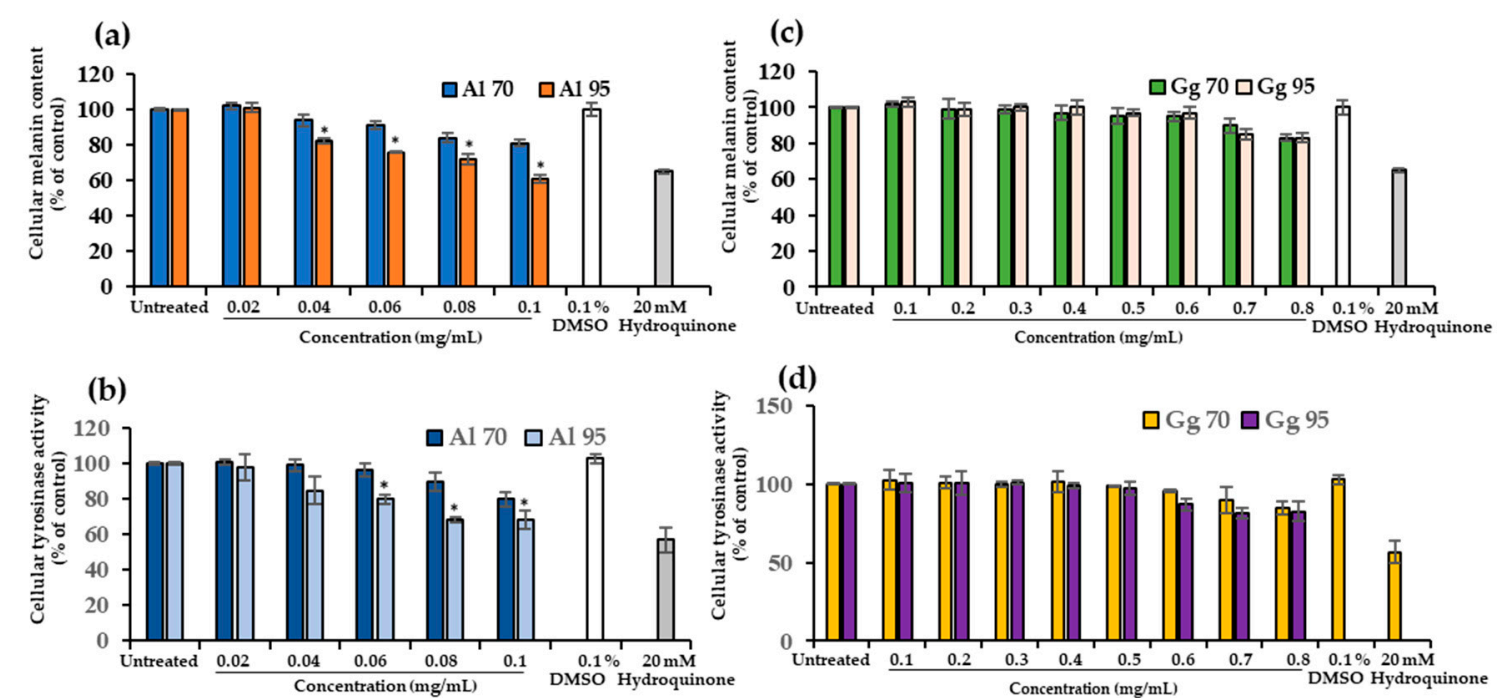

(d)

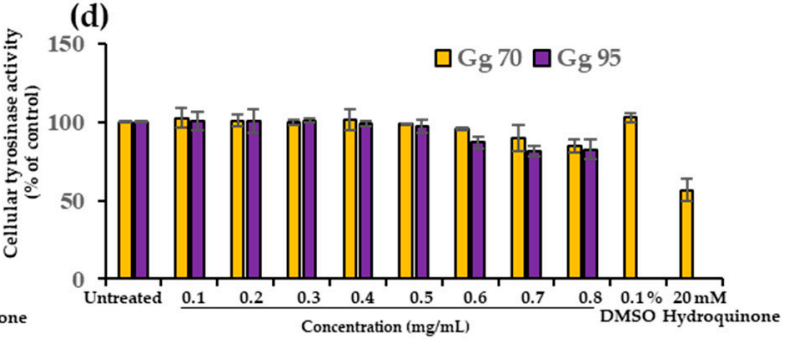

Figure 3. Effect of A. lakoocha and G. glabra extracts on cellular melanin content and tyrosinase activity. B16 cells were treated with Al70 and Al95 and evaluated for (a) cellular melanin content and (b) cellular tyrosinase activity. B16 cells treated with Gg70 and Gg95 monitored for (c) cellular melanin content and (d) cellular tyrosinase activity. Cells were treated with extracts for $48 \mathrm{~h}$ and data are means \pm SD from three independent experiments. The superscript letters $\left(^{*}\right)$ indicate significant difference at $p<0.01$.

\subsection{Combined Effects of A. lakoocha and G. glabra Extracts on Cellular Melanin Content and Tyrosinase Activity}

To determine the combined effects in B16 cells from A. lakoocha and G. glabra extracts on cytotoxicity, cellular melanin content, and tyrosinase activity, A195 and Gg95 extracts were used in combination, as shown in Figures 4 and 5. Cells were treated with A195 and Gg95 extracts, alone and in combination with A195 and Gg95 at the following ratios: 9:1, 7:1, 5:1, 3:1, 1:1, 1:3, 1:5, 1:7, and 1:9. The viability of $\mathrm{B} 16$ cells treated with $\mathrm{Al}$ and $\mathrm{Gg}$ extract at all ratios was nearly $100 \%$ of untreated control cells after $72 \mathrm{~h}$ (Figure 4). The combination of A195 and Gg95 extracts did not increase cytotoxicity toward B16 cells and no cytotoxicity was observed at a concentration of $0.1 \mathrm{mg} / \mathrm{mL}$. Interestingly, the combined A195 and Gg95 extracts were able to decrease melanin content in B16 cells (Figure 5a-c). A195 and Gg95 extracts combined at a ratio of 9:1 was especially effective in reducing the number of melanin containing cells ( $82 \pm 4.64$ cells/total 1000 cells) (Figure $5 b)$ and melanin content, showing a reduction of up to $53 \%$ (Figure $5 c)$. This was a significant reduction $(p<0.01)$ compared to Al95 extract alone, which exhibited the number of melanin containing cells $153 \pm 5.79$ cells per total 1000 cells and only $35 \%$ reduction in melanin pigment. Tyrosinase inhibitory activity was also significantly enhanced with this combined extract in B16 cells $(p<0.01)$ compared to A195 alone (Figure 5d). These results indicate that the combination of A. lakoocha and G. glabra extracts has an additive effect to inhibit tyrosinase activity, leading to a reduction in cellular melanin pigments without causing cytotoxicity. 


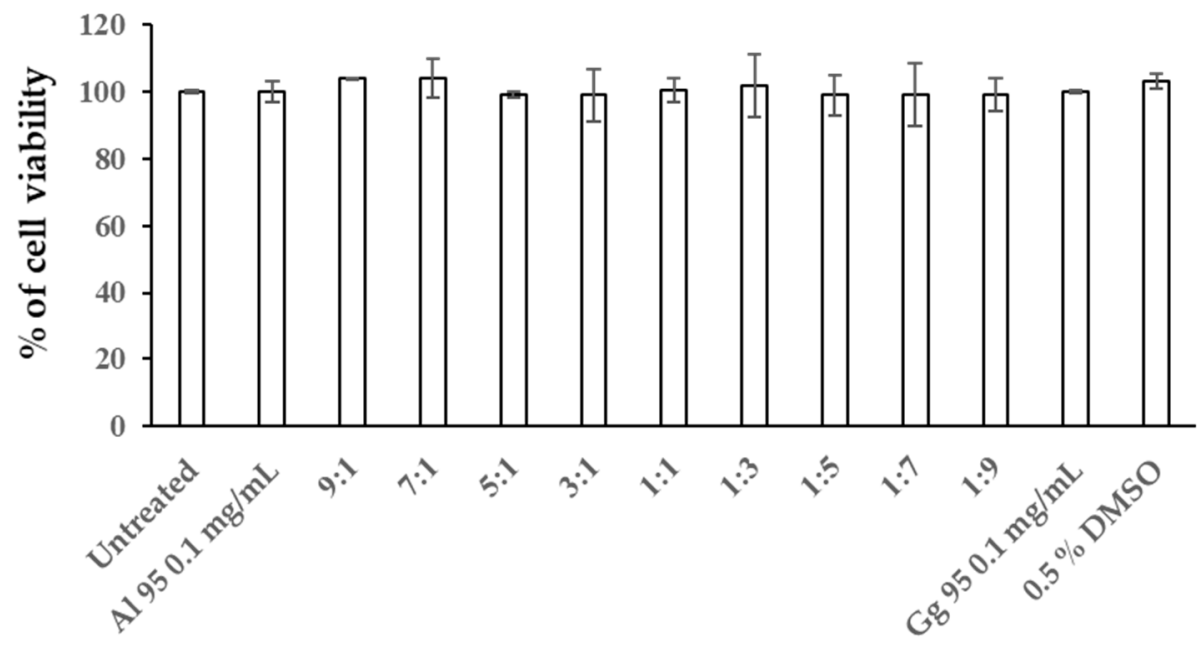

Figure 4. Cell viability of B16 cells exposed to mixtures of A. lakoocha and G. glabra extracts. Cells were treated with the combination of A195 and Gg95 extracts for $72 \mathrm{~h}$. Percentages of cell viability are means \pm SD from three independent experiments.

(a)

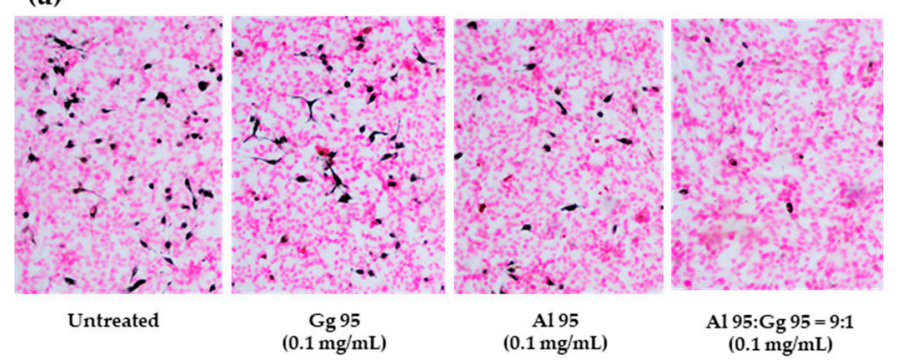

(b)

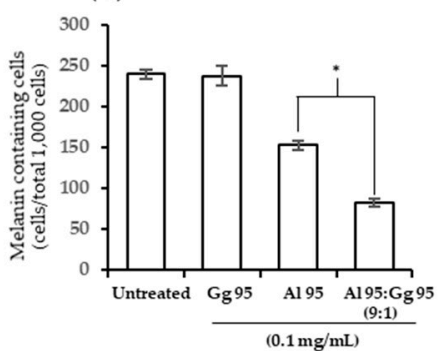

(c)

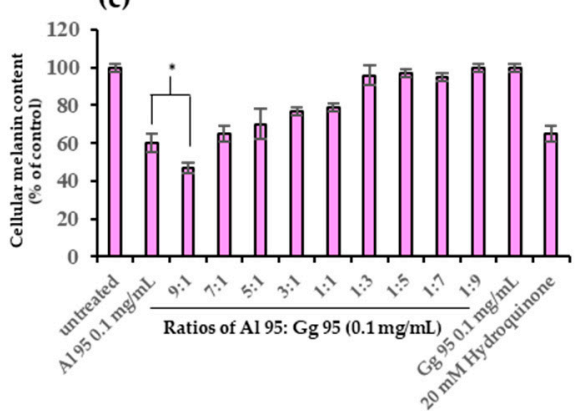

(d)

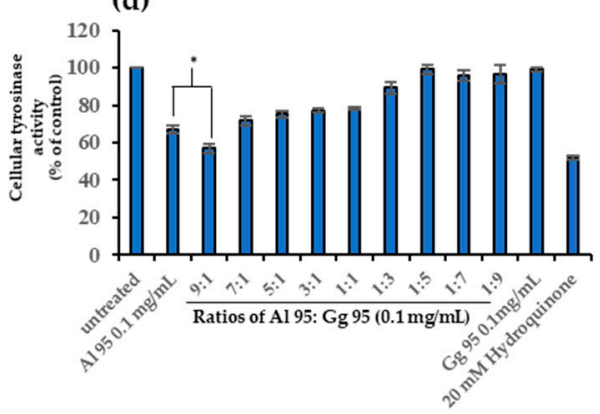

Figure 5. Effect of combined A. lakoocha and G. glabra on cellular melanin content and tyrosinase activity. (a) Melanin pigments (black) in B16 cells (pink) observed under a light microscope (Magnification $\times 100$ ); (b) the number of melanin containing cells from a total of 1000 cells counted under a light microscope; (c) cellular melanin content; (d) cellular tyrosinase activity. Cells were treated with combinations of Al95 and Gg95 at a final concentration of $0.1 \mathrm{mg} / \mathrm{mL}$ in several ratios for $48 \mathrm{~h}$. The data are means \pm SD from three independent experiments. The superscript letters $\left(^{*}\right)$ indicate significant difference at $p<0.01$.

\subsection{Effect of Combined A. lakoocha and G. glabra Extracts on Proteins Related to Melanogenesis in B16 Cells}

To identify a potential mechanism leading to reduced melanin accumulation following exposure to A195 and Gg95 extracts, expression levels of melanogenesis-related proteins, including MITF, TYR, TRP-1 and TRP-2 were evaluated by Western blots (Figure 6a). Combination of A195 and Gg95 extracts at a ratio of 9:1 significantly reduced MITF, TYR, and TRP-2 protein levels $(p<0.01)$ compared with A195 alone (Figure 6b). The A195 and Gg95 combination resulted in the maximum reduction of melanogenesis proteins among all conditions examined. The present findings suggest that the 
combination of Al95 and Gg95 extracts had an additive effect on the down regulation of MITF, TYR, and TRP-2 expression. The hypopigmentation effect due to exposure to the combination of A195 and Gg95 extracts is likely mediated through down-regulation of MITF gene expression, which would subsequently repress the expression of tyrosinase and TRP-2.

(a)

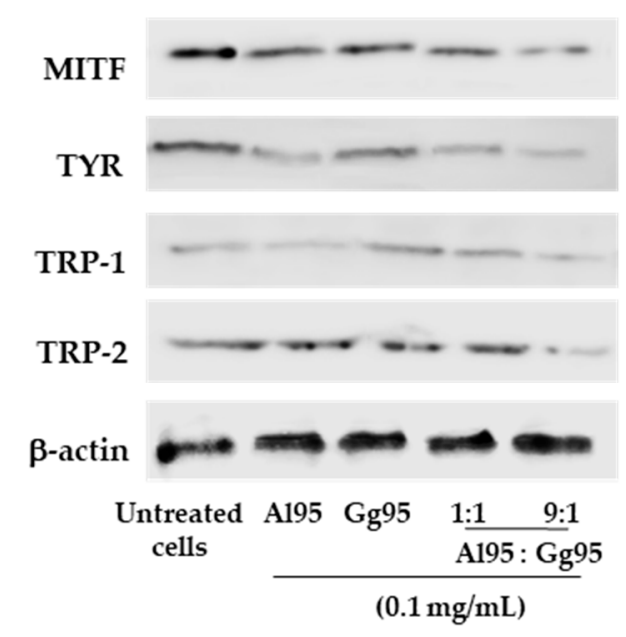

(b)
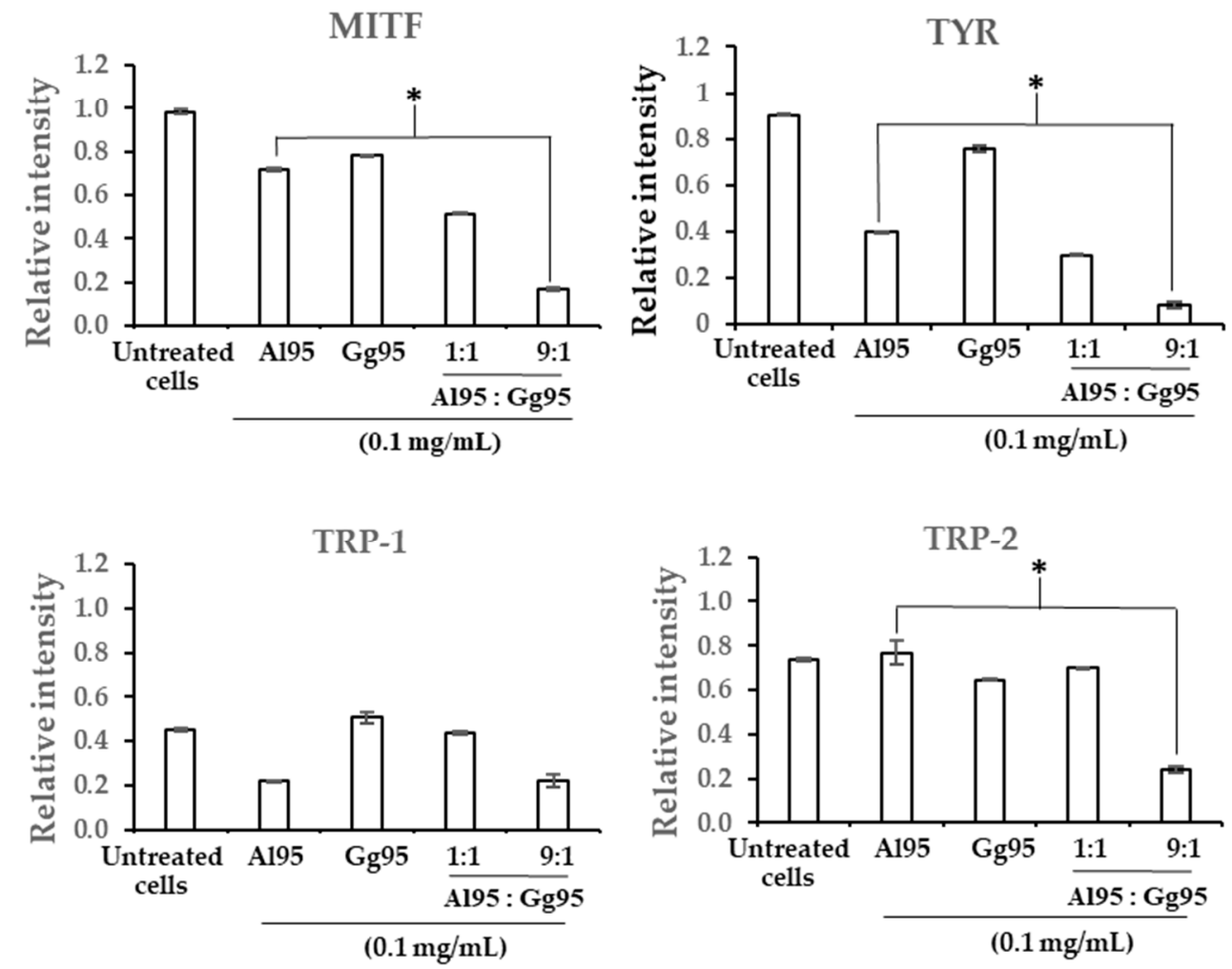

Figure 6. Inhibitory effect of combined A. lakoocha and G. glabra extracts on proteins related to melanogenesis. (a) Protein bands for microphthalmia-associated transcription factor (MITF), tyrosinase (TYR), tyrosinase-related protein (TRP)-1, TRP-2 and $\beta$-actin. (b) Relative intensity of protein levels of MITF, TYR, TRP-1, and TRP-2. Cells were treated with mixtures of A195 and Gg95 at final concentration of $0.1 \mathrm{mg} / \mathrm{mL}$ at ratios of $1: 1$ and 9:1 for $48 \mathrm{~h}$. The samples derive from the same experiment and blots were processed in parallel. The data are means \pm SD from three independent experiments. The superscript letters ${ }^{*}$ ) indicate significant difference at $p<0.01$. 


\section{Discussion}

In this study, a combination of $\mathrm{Al}$ and $\mathrm{Gg}$ extracts was investigated for cellular tyrosinase inhibitory activity, reduction of melanin contents and downregulated expression of melanogenesis-related genes MITF, TYR, TRP-1 and TRP-2 in melanoma B16 cells. This is the first report exhibiting additive activity of the combination of $\mathrm{Al}$ and $\mathrm{Gg}$ extracts to inhibit tyrosinase and reduce melanin pigments by suppressing the expression of MITF, TYR and TRP-2 in B16 cells.

Previously, Artocarpus lakoocha (Al) extracted with $95 \%$ ethanol was shown to contain higher total phenolic content and exhibit higher tyrosinase inhibitory activity compared to $\mathrm{Al}$ extracted with propylene glycol [29]. A high total phenolic content was also reported for $\mathrm{Al}$ extracted with $80 \%$ ethanol [33]. Extraction of Al using water, methanol, ethanol, propanol and butanol demonstrated that ethanol was the most effective solvent for isolating oxyresveratrol and resveratrol $[43,44]$. Similarly, Glycyrrhiza glabra $(\mathrm{Gg})$ extracted with ethanol had higher total phenolic and flavonoid contents than water extraction [45]. Glabribin and glycyrrhizic were more abundant from Gg extracted in ethanol compared to extracted that with water, methanol, acetonitrile, and chloroform [46]. In this study, $\mathrm{Al}$ and Gg were macerated in $70 \%$ and $95 \%$ ethanol and higher antioxidant and tyrosinase inhibitory activity was found when using 95\% ethanol. These results were consistent with the levels of total phenolic and flavonoid contents found in A195 and Gg95 extracts. In particular, oxyresveratrol and glabridin were more abundant in A195 and Gg95 extracts, respectively, compared to extracts prepared using $70 \%$ ethanol. $\mathrm{Al}$ and $\mathrm{Gg}$ extracted with ethanol are expected to contain oxyresveratrol and glabridin, respectively, and these compounds appear to possess tyrosinase inhibitory activity. The mushroom tyrosinase test is a simple analytical method to assess inhibitory activity of compounds or extracts. However, mushroom tyrosinase is different from mammalian tyrosinase due to its unique requirements for substrate and cofactors. In addition, the sensitivity of mushroom tyrosinase to inhibitors is distinct compared to the mammalian enzyme [47]. Another difference arises from protein modifications to these tyrosinase proteins. Mushroom tyrosinase is secreted, while mammalian tyrosinase is present in an inactive form that requires glycosylation in the Golgi apparatus and phosphoactivation by protein kinase $C$ beta (PKC $\beta$ ) [48-50]. Many plant extracts that show in vitro inhibitory activity against mushroom tyrosinase are unable to reduce pigmentation in cells [51]. Previously, crude extracts isolated from A. lakoocha and G. glabra have been found to have tyrosinase inhibitory activities and the ability to reduce melanin pigmentation as well as containing antioxidant and antimicrobial activities $[34,41-43,45,52,53]$. Similarly, Al and Gg extracts in this study were able to inhibit both mushroom and cellular tyrosinase activities and reduce melanin pigments in B16 cells.

Mixtures of compounds can often lead to more pronounced effects than the individual products $[54,55]$. Inhibition of melanin production by a combination of plant extracts had been reported previously. A combination of Siberian larch and pomegranate extracts exhibited a two-fold reduction in melanin content compared to S. larch or pomegranate extracts alone with no cytotoxicity to the cell. These combined extracts reduced expression of melanocyte specific genes, TYR, MITF, and melanosome structural proteins (melanocyte-specific glycoprotein (Pmel17) and melanoma antigen recognized by $\mathrm{T}$ cells 1 (Mart1)); however, inhibition of the tyrosinase enzyme was not observed [56]. A combination of chia seed and pomegranate fruit extracts exhibited an additive effect on the inhibition of melanin biosynthesis also with no corresponding effect on tyrosinase activity. The combination of chia seed and pomegranate fruit extracts is likely due to decreased expression of melanogenesis-related genes (TYR, TRP1, and melanocortin 1 receptor (MC1R)) [57]. In our study, a combination of A195 and Gg95 extracts, at concentrations that did not reduce the viability of B16 cells, was able to decrease melanin pigments as well as inhibit tyrosinase activity. These results indicate that a combination between A195 and Gg95 extracts additively effect the reduction of cellular melanin pigments. Investigation into the possible mechanism of action revealed that A195 extract alone downregulated expression of melanogenesis-related genes MITF, TYR, and TRP-1. While a combination of A195 with Gg95 extracts more significantly reduced expression of MITF, TYR, and TRP-2. The hypopigmentation effect of a combination of A195 and Gg95 extracts may potentially be the result of down-regulation of MITF gene 
expression. Reduced MITF levels may affect in turn repress the expression of tyrosinase and TRP-2, as MITF is a major regulator of the synthesis of tyrosinase-related proteins (TRPs), including TYR, TRP-1 and TRP2 [58,59].

Numerous topical products for skin whitening are available and contain active ingredients to reduce melanin production. Ascorbic acid and its derivatives, as active ingredients with anti-tyrosinase properties have been used in some commercial lightening products [60]. Ascorbic acid acts as a reducer to block the chain of oxidations transforming tyrosine into melanin and interacts with copper, an essential cofactor in tyrosinase activity [61]. This active ingredient is not used alone but always used in combination with another ingredient. A. lakoocha extract was reported to exhibit in vitro tyrosinase inhibitory activity as well as the ability to reduce in vivo melanin content in a human volunteer. It was suggested based on these findings that $A$. lakoocha extract has been proposed as a potential skin-whitening agent $[34,62]$. However, another report raised the concern that at high concentrations the A. lakoocha ethanolic extract may be toxic in the blood system [33]. Glabridin and glabrene from G. glabra are known to inhibit tyrosinase activity and have been used as depigmentation agents in cosmetics [25,42]. Induction of melanin pigments by UV-B was reduced by topical application of $0.5 \%$ glabridin [42]. The main drawbacks of glabridin are its poor skin-penetrating ability and instability in formulations [25]. The combination of A195 and Gg95 extracts has an additive effect on the reduction of melanin pigments, an alternative way to reduce the cytotoxicity of compounds in A195 extracts and improve skin-penetration of compound Gg95 extracts; however, this will be further investigated. Finally, this is the first study suggesting that combination between A. lakoocha and G. glabra extracts is useful in development of skin care products for skin hyperpigmentation disorders.

\section{Materials and Methods}

\subsection{Chemicals}

Tyrosinase from mushroom (SLBJ5647, activity of $5771 \mathrm{unit} / \mathrm{mg}$ ), 3,4-dihydroxy-L-phenylalanine (L-DOPA), dimethyl sulfoxide (DMSO), Folin and Ciocalteu's Phenol reagent, 2,2-diphenyl-1-picrylhydrazyl (DPPH), sodium dihydrogen phosphate, 3-(4,5-dimethylthaizol-2-yl)-2,5-diphenyltetrazolium bromide (MTT), kojic acid, gallic acid, quercetin, oxyresveratrol, resveratrol, and glabridin were purchased from Sigma-Aldrich, Inc. (St. Louis, MO, USA). Disodium hydrogen phosphate and disodium carbonate were supplied by Merck Millipore (Temecula, California, USA). L-ascorbic acid and aluminium choride were purchased from Ajax Finechem (Taren Point, Australia).

\subsection{Plant Materials and Extraction}

Dried powder of A. lakoocha $(\mathrm{Al})$ heartwood and G. glabra $(\mathrm{Gg})$ root was purchased from Vejpongosot Pharmacy (Bangkok, Thailand). The extraction methods of Al and Gg were modified from those previously described [43]. Briefly, one kilogram of dried plant material was macerated overnight in $5 \mathrm{~L}$ of $70 \%$ or $95 \%$ ethanol at room temperature for $\mathrm{Al}$ and at $48{ }^{\circ} \mathrm{C}$ for $\mathrm{Gg}$. After three rounds of maceration, the alcoholic extracts were pooled, filtered, and evaporated under reduced pressure below $45^{\circ} \mathrm{C}$. The yields of crude extracts for Al70, Al95, Gg70 and Gg95 were 9.703\%, 8.675\%, 8.46\% and $8.153 \%$, respectively.

\subsection{Determination of Total Phenolic Content}

The total phenolic compounds in $\mathrm{Al}$ and $\mathrm{Gg}$ extracts were detected using the Folin-Ciocalteu reagent, [63]. In 96-well plates, $4.5 \mu \mathrm{L}$ of $1 \mathrm{mg} / \mathrm{mL}$ extracts was diluted in $126 \mu \mathrm{L}$ of deionize water, the samples were mixed with $90 \mu \mathrm{L}$ of $2 \% \mathrm{Na} 2 \mathrm{CO} 3$ for 3 min and then $4.5 \mu \mathrm{L}$ of $50 \%$ Folin-Ciocalteu reagent was added. The samples were incubated at room temperature for $30 \mathrm{~min}$ and the resulting blue molybdenum-tungsten complex was monitored at $750 \mathrm{~nm}$ using a microplate reader (Biochrom EZ Read 2000, Cambridge, UK). The total phenolic content in each sample was calculated by comparison 
to a gallic acid standard and results are presented as milligrams of gallic acid equivalent to one gram of extract (mg GAE/g extract).

\subsection{Determination of Flavonoid Content}

The flavonoid compounds of $\mathrm{Al}$ and $\mathrm{Gg}$ extracts were determined using the aluminum chloride assay [64]. In 96-well plates, $100 \mu \mathrm{L}$ of $1 \mathrm{mg} / \mathrm{mL}$ extracts were mixed with $100 \mu \mathrm{L}$ of $2 \% \mathrm{AlCl} 3$. Following incubation at room temperature for $10 \mathrm{~min}$, the absorbance was monitored at $415 \mathrm{~nm}$ with a microplate reader (Biochrom EZ Read 2000, Cambridge, UK). The total flavonoid content of samples was analyzed by comparison to quercetin standard and the results were presented as quercetin equivalent (mg QE/g extract).

\subsection{Phytochemical Screening Assay}

Chemical composition was determined using Ultra High Performance Liquid Chromatography (UHPLC) modified as previously described [31,43]. UHPLC analysis was performed using a Thermo Scientific UHPLC UltiMate 3000 (Waltham, MA, USA) with a Hypersil GOLD ${ }^{\mathrm{TM}}$ a Q column $\left(100 \times 2.1 \mathrm{~mm}\right.$ i.d., $1.9 \mu \mathrm{m}$, Thermo Scientific $\left.{ }^{\mathrm{TM}}\right)$ and results were analyzed with Thermo Scientific ${ }^{\mathrm{TM}}$ LCQUAN ${ }^{\mathrm{TM}}$ software. Crude extracts of $\mathrm{Al}$ and $\mathrm{Gg}$ and standard solutions (oxyresveratrol, resveratrol, gallic acid and glabridin) were dissolved in methanol at concentrations of 1 and $10 \mathrm{mg} / \mathrm{mL}$. Samples were filtered $(0.20 \mathrm{~mm}$, Millipore) and $1 \mu \mathrm{L}$ was directly injected. Solvents for HPLC analysis were formic acid $(0.1 \% v / v)$ in water as solvent $\mathrm{A}$ and formic acid $(0.1 \% v / v)$ in methanol as solvent $\mathrm{B}$, at a flow rate of $0.5 \mathrm{~mL} / \mathrm{min}$. These experiments used the following gradient: $30 \%$ B linear (0-4 min), 30-50\% B linear (4-5 min), 50-70\% B linear (5-8 min), 70-100\% B linear (8-12 min), 100\% B (12-15 min), and $30 \% \mathrm{~B}$ linear (15-18 $\mathrm{min}$ ). An equilibrium period of $5 \mathrm{~min}$ was performed prior to the injection of subsequent samples. Chromatograms were recorded at $280 \mathrm{~nm}$ (glabridin and gallic acid), $305 \mathrm{~nm}$ (resveratrol), and $326 \mathrm{~nm}$ (oxyresveratrol), using the photodiode detector. Quantitative determination of compounds was performed using peak area with an external standard.

\subsection{2,2-di-phenyl-1-picrylhydrazyl (DPPH) Radical Scavenging Assay}

Antioxidant activity of $\mathrm{Al}$ and $\mathrm{Gg}$ extracts was determined based on DPPH scavenging ability [65]. Seventy-five microliters of the extracts at various concentrations $(0.015-1 \mathrm{mg} / \mathrm{mL})$ were mixed with $150 \mu \mathrm{L}$ of $0.2 \mathrm{mM}$ DPPH, incubated for $30 \mathrm{~min}$, and the absorbance at $515 \mathrm{~nm}$ was monitored using a microplate reader (Biochrom EZ Read 2000, UK). Ethanol was used as the blank solution and L-ascorbic acid was the positive control. The scavenging activity of DPPH radicals was calculated and expressed as a percentage of the blank. The $\mathrm{IC}_{50}$ value represents the concentration of extract capable of reducing DPPH by $50 \%$, calculated using a linear regression graph.

\subsection{Mushroom Tyrosinase Assays}

Inhibition of mushroom tyrosinase activity was detected using L-3,4-dihydroxyphenylalanine (L-DOPA) as a substrate [66]. Briefly, $20 \mu \mathrm{L}$ of extracts at various concentrations $(0.0024-1.25 \mathrm{mg} / \mathrm{mL})$, $140 \mu \mathrm{L}$ of $20 \mathrm{mM}$ phosphate buffer ( $\mathrm{pH}$ 6.8), and $20 \mu \mathrm{L}$ of $461.68 \mathrm{unit} / \mathrm{mL}$ of mushroom tyrosinase were added to each well of a 96-well plate. Samples were mixed for $10 \mathrm{~min}, 20 \mu \mathrm{L}$ of $4 \mathrm{mM} \mathrm{L}$-DOPA was then added and this was followed by incubation at $37^{\circ} \mathrm{C}$ for $30 \mathrm{~min}$. The relative amount of dopachrome formed in the mixture was monitored by measuring the absorbance at $475 \mathrm{~nm}$ using a microplate reader (Biochrom EZ Read 2000, UK). Tyrosinase and L-DOPA only solutions were used as a negative control. Kojic acid at concentrations ranging from 0.0024 to $1.25 \mathrm{mg} / \mathrm{mL}$ was a positive control. The inhibition of tyrosinase activity was calculated and presented as a percentage of the control. The IC50 for tyrosinase inhibition was calculated using a linear regression graph and is the concentration of extract capable of reducing tyrosinase activity to $50 \%$. 


\subsection{Cell Viability Assay}

Cell viability of B16 cells was determined with the MTT assay to establish the non-cytotoxic concentrations of $\mathrm{Al}$ and $\mathrm{Gg}$ extracts [67]. B16 melanoma cells (RIKEN Cell Bank, Tsukuba, Japan) were cultured in Dulbecco's Modified Eagle's Medium (DMEM, Gibco ${ }^{\circledR} /$ Thermo Scientific, Waltham, MA, USA) with $10 \%$ fetal bovine serum (FBS) and penicillin/streptomycin $(50 \mu \mathrm{g} / \mathrm{mL})$ in an incubator with $5 \% \mathrm{CO} 2$ at $37^{\circ} \mathrm{C}$. Briefly, $3.0 \times 10^{4}$ cells were plated into 96 -well plates and incubated at $37^{\circ} \mathrm{C}$ overnight. After removal of the culture medium, cells were treated for $72 \mathrm{~h}$ wth $200 \mu \mathrm{L}$ of extracts, diluted with medium at various concentrations of $0.02-0.12 \mathrm{mg} / \mathrm{mL}$ and $0.1-1 \mathrm{mg} / \mathrm{mL}$ for the $\mathrm{Al}$ and $\mathrm{Gg}$ extracts, respectively. The culture media with extracts was removed and treated cells were then added with $100 \mu \mathrm{L}$ of $0.5 \mathrm{mg} / \mathrm{mL}$ MTT solution. After additional $2 \mathrm{~h}$, the formazan crystals were dissolved with $100 \mu \mathrm{L}$ of dimethyl sulfoxide (DMSO). The absorbance was monitored at $530 \mathrm{~nm}$ using a microplate reader (1420 Victor 2, Wallac, Ramsey, MN, USA). The results were presented as the percentage of viable cells (\% cell viability) by comparing with untreated cells as a control.

\subsection{Melanin Content Assay}

Melanin content in B16 cells was evaluated as described previously [68]. In brief, $1.5 \times 10^{5} \mathrm{~B} 16$ cells were plated into 24-well plates and incubated overnight to allow cells to adhere. Cells were treated for $48 \mathrm{~h}$ with various concentrations of $0.02-0.1 \mathrm{mg} / \mathrm{mL}$ and $0.1-0.8 \mathrm{mg} / \mathrm{mL}$ for $\mathrm{Al}$ and $\mathrm{Gg}$ extracts, respectively. After cells were harvested using trypsin, the cell pellet was resuspended with $100 \mu \mathrm{L}$ of $1 \mathrm{~N} \mathrm{NaOH}, 1 \%$ Triton X-100, $1 \mathrm{mM}$ phenylmethanesulfonyl fluoride (PMSF) and incubated at $60^{\circ} \mathrm{C}$ for $1 \mathrm{~h}$ to allow cell lysis. Melanin content of lysates was monitored at $405 \mathrm{~nm}$ using a microplate reader (1420 Victor 2, Wallac, USA). Hydroquinone at $20 \mathrm{mM}$ was used as a positive melanin inhibitor. Melanin content was presented as a percentage of the value obtained for untreated control cells.

Accumulation of melanin pigments and cellular morphology of B16 cells were observed with a Masson-Fontana stain using a procedure modified from that previously described [69]. In brief, $5.0 \times 10^{5} \mathrm{~B} 16$ cells $/ \mathrm{mL}$ were plated into 6-well plates for $24 \mathrm{~h}$. Cells were treated with non-toxic doses of extracts and incubated for 3 days. Treated cells were fixed with absolute ethanol and rehydrated with distilled water. Cells were then stained with an ammoniacal silver solution for $24 \mathrm{~h}$, sodium thiosulfate for $5 \mathrm{~min}$ and Mayer's Carmalum for $10 \mathrm{~min}$. Melanin pigments and cellular morphology were observed under a light microscope at a magnification of $100 \times$. The number of melanin containing cells were calculated from a total of 1000 cells counted.

\subsection{Cellular Tyrosinase Activity Assay}

Tyrosinase activity from B16 cells was determined using L-DOPA [70]. B16 cells, $1.0 \times 10^{5} \mathrm{cell} / \mathrm{well}$ were plated into a 24-well plate and incubated overnight to allow cells to adhere. Cells were treated for $48 \mathrm{~h}$ with various concentrations of $0.02-0.1 \mathrm{mg} / \mathrm{mL}$ and $0.1-0.8 \mathrm{mg} / \mathrm{mL}$ for $\mathrm{Al}$ and $\mathrm{Gg}$ extracts, respectively, and harvested. Cell pellets were lysed with $100 \mu \mathrm{L}$ of $0.1 \%$ Triton X-100 and $0.1 \mathrm{mM}$ PMSF (pH 7.5) in phosphate buffer saline (PBS). Lysates were clarified by centrifugation at $12,000 \times g$ at $4{ }^{\circ} \mathrm{C}$ for $15 \mathrm{~min}$ to obtain the supernatant. Reaction mixtures consisting of $80 \mu \mathrm{L}$ of supernatant and $20 \mu \mathrm{L}$ of $20 \mathrm{mM}$ L-DOPA were determined after incubation at $37^{\circ} \mathrm{C}$ for $60 \mathrm{~min}$. The optical densities were measured at $492 \mathrm{~nm}$ using a microplate reader (1420 Victor 2, Wallac, Ramsey, MN, USA). Sodium L-lactate (SLL) at a concentration of $20 \mathrm{mM}$ was used as a positive control. The cellular tyrosinase activity was calculated and presented as a percentage of the control ( $100 \%$ for untreated cells).

\subsection{Evaluation of Additive Effects of Al and Gg Extracts on Cellular Melanin Content and Tyrosinase Activity}

Combinations between $\mathrm{A} 195$ and $\mathrm{Gg} 95$ extracts were evaluated for inhibition of tyrosinase activity and melanin production in B16 cells. Mixtures of $\mathrm{Al}$ and $\mathrm{Gg}$ extracts was prepared at ratios of 9:1, 7:1, 5:1, 3:1, 1:1, 1:3, 1:5, 1:7 and 1:9. The final concentration of all combined extracts of $\mathrm{Al}$ and $\mathrm{Gg}$ was 
$0.1 \mathrm{mg} / \mathrm{mL}$. These combined extracts were evaluated for cytotoxicity, inhibition of tyrosinase activity, and effects on melanin pigments in melanoma B16 cells.

\subsection{Western Blot Analysis}

The abundance of proteins involved in melanogenesis was determined using Western blot analysis, modified from the procedure previously described [71]. Briefly, $1.0 \times 10^{5}$ cells were plated into the 6 well plates and incubated at $37^{\circ} \mathrm{C}, 5 \% \mathrm{CO} 2$ for $24 \mathrm{~h}$. Following removal of the old media, $2 \mathrm{~mL}$ of conditioned media containing combined $\mathrm{Al}$ and $\mathrm{Gg}$ extracts at ratios of 1:1 and 9:1 and single extract in final concentration at $0.1 \mathrm{mg} / \mathrm{mL}$ was added and samples were incubated at $37^{\circ} \mathrm{C}, 5 \% \mathrm{CO} 2$ for $48 \mathrm{~h}$. Treated cells were harvested and lysed in $100 \mu \mathrm{L}$ radioimmunoprecipitation assay buffer (RIPA) buffer. Protein content was determined using a protein quantitation kit (Merck, Darmstadt, Germany). Total protein, $20 \mu \mathrm{g}$, from each sample was separated using 12\% SDS-PAGE and transferred to polyvinylidene difluoride (PVDF) membranes. Membranes were treated separately with the following primary antibodies at the indicated dilutions at room temperature for $1 \mathrm{~h}$ with gentle agitation: rabbit anti-mouse tyrosinase (immunoglobulin G (IgG) (1:100), rabbit anti-mouse TRP-1 IgG (1:200), rabbit anti-mouse TRP-2 IgG (1:100), goat anti-mouse MITF IgG (1:200) and rabbit anti-mouse $\beta$-actin

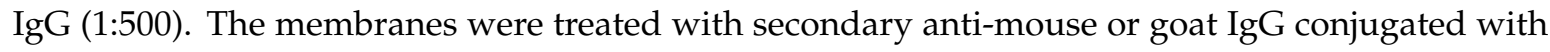
horseradish peroxides (1:2000). Protein bands were visualized with enhanced chemiluminescence (ECL) with a Gel documentation system and quantitated using Image J software.

\subsection{Statistical Analysis}

All grouped data were evaluated with SPSS version 17. Data were expressed as the mean \pm SD of three independent experiments and analyzed for statistical significance using t-test and one-way ANOVA. Differences were considered statistically significant at $p<0.01$.

\section{Conclusions}

Artocarpus lakoocha (Al) and Glycyrrhiza glabra $(\mathrm{Gg})$ extracts prepared using 95\% ethanol had high antioxidant and tyrosinase inhibitory activity as well as a high total phenolic and flavonoid contents. Oxyresveratrol and glabridin were major components found in A195 and Gg 95 extracts, respectively, and these compounds appear to possess tyrosinase inhibitory activity. Interestingly, $\mathrm{Al}$ and $\mathrm{Gg}$ extracts exhibited the inhibition of both mushroom and cellular tyrosinase activities, and reduction of melanin pigments in B16 cells. A combination of A195 and Gg95 extracts was able to reduce melanin pigments and enhance tyrosinase inhibitory activity in B16 cells when compared to A195 alone, without decreasing cell viability. The combination of A195 and Gg95 extracts appears to exhibit an additive effect to reduce melanin pigments. The enhanced inhibitory effect of the $\mathrm{Al}$ and $\mathrm{Gg}$ extract mixture may be due to the action of oxyresveratrol and glabridin. Based on the findings, we propose that an effective melanin reduction strategy should target multiple pathways of melanin synthesis through the action of a mixture of ingredients. These findings suggest that the combination of A. lakoocha and G. glabra extracts is a new approach to treat skin hyperpigmentation disorders.

Author Contributions: Conceptualization, T.P. and P.S.; methodology, T.R., C.T., N.B., R.R. and P.Y.; software, T.P. and T.R.; validation, T.R., C.T. and R.R.; formal analysis, T.P. and P.S.; investigation, T.P.; resources, T.P.; data curation, T.P., P.S. and T.R.; writing—original draft preparation, T.P. and T.R.; writing-review and editing, T.P.; visualization, T.P.; supervision, T.P.; project administration, T.P.; funding acquisition, T.P. All authors have read and agreed to the published version of the manuscript.

Funding: This research was funded by National Research Council of Thailand (NRCT), Ministry of Higher Education, Science, Research and Innovation, Thailand for funding the work through the research project No. (602036).

Acknowledgments: We would like to thank the Central Chemistry and Cosmetic Science Laboratories, Faculty of Science and Technology, Suan Dusit Universtiy for assistance with plant extractions. We thank Department of Pathobiology, Faculty of Science, Mahidol University for use of their cell culture facility and thank Lt. Col. Sarawut Jindarat, Department of Pharmacology, Phramongkutklao College of Medicine for compound analysis 
and Laran Jensen, a native English speaker, Department of Biochemistry, Faculty of Science, Mahidol University for critical reading and English editing of this manuscript.

Conflicts of Interest: The authors declare no conflict of interest.

\section{References}

1. Meyskens, F.L., Jr.; Farmer, P.; Fruehauf, J.P. Redox regulation in human melanocytes and melanoma. Pigment Cell Res. 2001, 14, 148-154. [CrossRef]

2. Kobayashi, T.; Vieira, W.D.; Potterf, B.; Sakai, C.; Imokawa, G.; Hearing, V.J. Modulation of melanogenic protein expression during the switch from eu- to pheomelanogenesis. J. Cell Sci. 1995, 108, 2301-2309.

3. Kim, S.S.; Kim, M.J.; Choi, Y.H.; Kim, B.K.; Kim, K.S.; Park, K.J.; Park, S.M.; Lee, N.; Hyun, C.G. Down-regulation of tyrosinase, TRP-1, TRP-2 and MITF expressions by citrus press-cakes in murine B16 F10 melanoma. Asian Pac. J. Trop. Biomed. 2013, 3, 617-622. [CrossRef]

4. Land, E.J.; Ramsden, C.A.; Riley, P.A. Tyrosinase autoactivation and the chemistry of ortho-quinone amines. Acc. Chem. Res. 2003, 36, 300-308. [CrossRef]

5. Tachibana, M. Cochlear melanocytes and MITF signaling. J. Investig. Dermatol. Symp. Proc. 2001, 6, 95-98. [CrossRef]

6. Yen, F.L.; Wang, M.C.; Liang, C.J.; Ko, H.H.; Lee, C.W. Melanogenesis Inhibitor(s) from Phyla nodiflora Extract. Evid. Based Complement. Alternat. Med. 2012, 2012, 867494. [CrossRef]

7. Kobayashi, T.; Urabe, K.; Winder, A.; Jiménez-Cervantes, C.; Imokawa, G.; Brewington, T.; Solano, F.; García-Borrón, J.C.; Hearing, V.J. Tyrosinase related protein 1 (TRP1) functions as a DHICA oxidase in melanin biosynthesis. EMBO J. 1994, 13, 5818-5825. [CrossRef]

8. Ye, Y.; Chu, J.H.; Wang, H.; Xu, H.; Chou, G.X.; Leung, A.K.; Fong, W.F.; Yu, Z.L. Involvement of p38 MAPK signaling pathway in the anti-melanogenic effect of San-bai-tang, a Chinese herbal formula, in B16 cells. J. Ethnopharmacol. 2010, 132, 533-535. [CrossRef]

9. Levy, C.; Khaled, M.; Fisher, D.E. MITF: Master regulator of melanocyte development and melanoma oncogene. Trends Mol. Med. 2006, 12, 406-414. [CrossRef]

10. Tsang, T.F.; Ye, Y.; Tai, W.C.; Chou, G.X.; Leung, A.K.; Yu, Z.L.; Hsiao, W.L.J. Inhibition of the p38 and PKA signaling pathways is associated with the anti-melanogenic activity of Qian-wang-hong-bai-san, a Chinese herbal formula, in B16 cells. Ethnopharmacology 2012, 141, 622-628. [CrossRef]

11. Buscà, R.; Ballotti, R. Cyclic AMP a key messenger in the regulation of skin pigmentation. Pigment Cell Res. 2000, 13, 60-69. [CrossRef]

12. Chang, T.S. An updated review on tyrosinase inhibitors. Int. J. Mol. Sci. 2009, 10, 2400-2475. [CrossRef]

13. Huang, W.Y.; Lee, P.C.; Huang, L.K.; Lu, L.P.; Liao, W.C. Stability studies of ascorbic acid 2-glucoside in cosmetic lotion using surface response methodology. Bioorg. Med. Chem. Lett. 2013, 23, 1583-1587. [CrossRef]

14. Shivhare, A.; Ambrose, S.J.; Zhang, H.; Purves, R.W.; Scott, R.W. Stable and recyclable Au25 clusters for the reduction of 4-nitrophenol. Chem. Commun. 2013, 49, 276-278. [CrossRef]

15. Yao, C.; Oh, J.H.; Oh, I.G.; Park, C.H.; Chung, J.H. [6]-Shogaol inhibits melanogenesis in B16 mouse melanoma cells through activation of the ERK pathway. Acta Pharmacol. Sin. 2013, 34, 289-294. [CrossRef]

16. Gonçalez, M.L.; Correa, M.A.; Chorilli, M. Skin delivery of kojic acid-loaded nanotechnology-based drug delivery systems for the treatment of skin aging. Biomed. Res. Int. 2013, 2013. [CrossRef]

17. Kumar, D.; Ghosh, R.; Pal, B.C. Glucosidase inhibitory terpenoids from Potentilla fulgens and their quantitative estimation by validated HPLC method. J. Funct. Foods 2013, 5, 1135-1141. [CrossRef]

18. Son, K.H.; Heo, M.Y. The evaluation of depigmenting efficacy in the skin for the development of new whitening agents in Korea. Int. J. Cosmet. Sci. 2013, 35, 9-18. [CrossRef]

19. Eimpunth, S.; Wanitphadeedecha, R.; Manuskiatti, W. A focused review on acne-induced and aesthetic procedure-related post-inflammatory hyperpigmentation in Asians. J. Eur. Acad. Dermatol. Venereol. 2013, 27, 7-18. [CrossRef]

20. Hsieh, P.W.; Chen, W.Y.; Aljuffali, I.A.; Chen, C.C.; Fang, J.Y. Co-drug strategy for promoting skin targeting and minimizing the transdermal diffusion of hydroquinone and tranexamic acid. Curr. Med. Chem. 2013, 20, 4080-4092. [CrossRef]

21. Tse, T.W.; Hui, E. Tranexamic acid: An important adjuvant in the treatment of melasma. J. Cosmet. Dermatol. 2013, 12, 57-66. [CrossRef] [PubMed] 
22. Carmen, P.; Laurian, V.; Mircea, T. Natural Resources Containing Arbutin. Determination of Arbutin in the Leaves of Bergenia crassifolia (L.) Fritsch. acclimated in Romania. Not. Bot. Horti Agrobot. Cluj Napoca 2009, 37, 129-132.

23. Amer, M.; Metwalli, M. Topical hydroquinone in the treatment of some hyperpigmentary disorders. Int. J. Dermatol. 1998, 37, 449-450. [CrossRef]

24. Haddad, A.L.; Matos, L.F.; Brunstein, F.; Ferreira, L.M.; Silva, A.; Costa, D., Jr. A clinical, prospective, randomized, double-blind trial comparing skin whitening complex with hydroquinone vs. placebo in the treatment of melasma. Int. J. Dermatol. 2003, 42, 153-156. [CrossRef]

25. Nerya, O.; Vaya, J.; Musa, R.; Izrael, S.; Arie, B.R.; Tamir, S. Glabrene and Isoliquiritigenin as Tyrosinase Inhibitors from Licorice Roots. J. Agric. Food Chem. 2003, 51, 1201-1207. [CrossRef] [PubMed]

26. Ookubo, N.; Michiue, H.; Kitamatsu, M.; Kamamura, M.; Nishiki, T.; Ohmori, I.; Matsui, H. The transdermal inhibition of melanogenesis by a cell-membrane-permeable peptide delivery system based on poly-arginine. Biomaterials 2014, 35, 4508-4516. [CrossRef]

27. Fujimoto, N.; Watanabe, H.; Nakatani, T.; Roy, G.; Ito, A. Induction of thyroid tumours in (C57BL/6N $\times$ C3H/N)F1 mice by oral administration of kojic acid. Food Chem. Toxicol. 1998, 36, 697-703. [CrossRef]

28. Takizawa, T.; Mitsumori, K.; Tamura, T.; Nasu, M.; Ueda, M.; Imai, T.; Hirose, M. Hepatocellular tumor induction in heterozygous p53-deficient CBA mice by a 26-week dietary administration of kojic acid. Toxicol. Sci. 2003, 73, 287-293. [CrossRef] [PubMed]

29. Teeranachaideekul, V.; Nithitanakool, S.; Junhunkit, T.; Ponpanich, L.; Nopporn, N.; Detamornrat, U.; Chulasiri, M. Liposomes: A novel carrier system for Artocarpus lakoocha extract to improve skin whitening. J. Asian Assoc. Sch. Pharm. 2013, 2, 243-253.

30. Salguero, C.P. The tradition of Thai medicine. In A Thai Herbal: Traditional Recipes for Health and Harmony; Barton, L., Ed.; Findhorn Press Scotland: Forres, UK, 2003; pp. 1-19.

31. Maneechai, S.; Likhitwitayawuid, K.; Sritularak, B.; Palanuvej, C.; Ruangrungsi, N.; Sirisa-Ard, P. Quantitative analysis of oxyresveratrol content in Artocarpus lakoocha and Puag-Haad. Med. Princ. Pract. Int. J. Kuwait Univ. Health Sci. Cent. 2009, 18, 223-227. [CrossRef]

32. Sritularak, B.; De-Eknamkul, W.; Likhitwitayawuid, K. Tyrosinase inhibitors from Artocarpus lackoocha. Thai J. Pharm. Sci. 1998, 22, 149-155.

33. Singhatong, S.; Leelarungrayub, D.; Chaiyasut, C. Antioxidant and toxicity activites of Artocarpus lakoocha Roxb. Heartwood extract. J. Med. Plants Res. 2010, 4, 947-953.

34. Tengamnuay, P.; Pengrungruangwong, K.; Pheansri, I.; Likhitwitayawuid, K. Artocarpus lakoocha heartwood extract as a novel cosmetic ingredient: Evaluation of the in vitro anti-tyrosinase and in vivo skin whitening activities. Int. J. Cosmet. Sci. 2006, 28, 269-276. [CrossRef] [PubMed]

35. Likhitwitayawuid, K.; Sornsute, A.; Sritularak, B.; Ploypradith, P. Chemical transformations of oxyresveratrol (trans-2,4,3',5'-tetrahydroxystilbene) into a potent tyrosinase inhibitor and a strong cytotoxic agent. Bioorg. Med. Chem. Lett. 2006, 16, 5650-5653. [CrossRef] [PubMed]

36. Hiroaki, H.; Hiroshi, S. Economic importance of licorice. Plant. Biotechnol. 2009, 26, 101-104.

37. Russo, M.; Serra, D.; Suraci, F.; Di Sanzo, R.; Fuda, S.; Postorino, S. The potential of e-nose aroma profiling for identifying the geographical origin of licorice (Glycyrrhiza glabra L.) roots. Food Chem. 2014, 165, 467-474. [CrossRef]

38. Marjan, N.H.; Hossein, H. Review of pharmacological effects of Glycyrrhiza sp. And its bioactive compounds. Phytother. Res. 2008, 22, 709-724.

39. Kawaguchi, Y.; Gou, K.; Kawa, Y.; Kashima, M.; Mizoguchi, M. The inhibitory effects of licorice extracts on melanogenesis: In vivo studies. Jpn. J. Dermatol. 1992, 102, 689-694.

40. Kameyama, K.; Sakai, C.; Tagawa, M. Effect of oil-soluble licorice extract on melanogenesis. Pigment Cell Res. 1994, 7, 372.

41. Fu, B.; Li, H.; Wang, X.; Lee, F.S.; Cui, S. Isolation and identification of flavonoids in licorice and a study of their inhibitory effects on tyrosinase. J. Agric. Food Chem. 2005, 53, 7408-7414. [CrossRef]

42. Yokota, T.; Nishio, H.; Kubota, Y.; Mizoguchi, M. The inhibitory effect of glabridin from licorice extracts on melanogenesis and inflammation. Pigment Cell Res. 1998, 11, 355-361. [CrossRef] [PubMed]

43. Povichit, N.; Phrutivorapongkul, A.; Suttajit, M.; Leelapornpisid, P. Antiglycation and antioxidant activities of oxyresveratrol extracted from the heartwood of Artocarpus lakoocha Roxb. Maejo Int. J. Sci. Technol. 2010, 4, 454-461. 
44. Borah, H.J.; Singhal, R.; Hazarika, S. Artocarpus lakoocha roxb: An untapped bioresource of resveratrol from North East India, its extractive separation and antioxidant activity. Ind. Crops Prod. 2017, 950, 75-82. [CrossRef]

45. Mohammed, S.K. Antioxidative activities of aqueous and ethanolic extracts of licorice roots. Pak. J. Nutr. 2014, 13, 267-270. [CrossRef]

46. Tian, M.; Yan, H.; Row, K.H. Extraction of Glycyrrhizic acid and Glabridin from licorice. Int. J. Mol. Sci. 2008, 9, 571-577. [CrossRef] [PubMed]

47. Espin, J.C.; García-Ruiz, P.A.; Tudela, J.; García-Cánovas, F. Study of stereospecificity in mushroom tyrosinase. Biochem. J. 1998, 331, 547-551. [CrossRef]

48. Bae-Harboe, Y.S.; Park, H.Y. Tyrosinase: A central regulatory protein for cutaneous pigmentation. J. Investig. Dermatol. 2012, 132, 2678-2680. [CrossRef]

49. Videira, I.F.; Moura, D.F.; Magina, S. Mechanisms regulating melanogenesis. An. Bras. Dermatol. 2013, 88, 76-83. [CrossRef] [PubMed]

50. Park, H.Y.; Wu, C.; Yaar, M.; Stachur, C.M.; Kosmadaki, M.; Gilchrest, B.A. Role of BMP-4 and Its Signaling Pathways in Cultured Human Melanocytes. Int. J. Cell Biol. 2009, 2009. [CrossRef]

51. Funayama, M.; Arakawa, H.; Yamamoto, R.; Nishino, T.; Shin, T.; Murao, S. Effects of alpha- and beta-arbutin on activity of tyrosinases from mushroom and mouse melanoma. Biosci. Biotechnol. Biochem. 1995, 59, 143-144. [CrossRef]

52. Teanpaisan, R.; Ruangkiatkul, P.; Thammasitboon, K.; Puripattanavong, J.; Faroongsarng, D. Effectiveness of Artocarpus lakoocha extract, poloxamer 407, on Enterococcus faecalis in vitro. J. Investig. Clin. Dent. 2013, 4, 219-224. [CrossRef] [PubMed]

53. Suhartati, T.; Yandri, H.; Hadi, S. The bioactivity test of artonin E from the bark of Artocarpus rigida Blume. Eur. J. Sci. Res. 2008, 23, 330-337.

54. Heinrich, M.; Heneka, B.; Ankli, A.; Rimpler, H.; Sticher, O.; Kostiza, T. Spasmolytic and antidiarrhoeal properties of the Yucatec Mayan medicinal plant Casimiroa tetrameria. J. Pharm. Pharmacol. 2005, 57, 1081-1085. [CrossRef]

55. Verpoorte, R.; Choi, Y.H.; Kim, H.K. Ethnopharmacology and systems biology: A perfect holistic match. J. Ethnopharmacol. 2005, 100, 53-56. [CrossRef] [PubMed]

56. Diwakar, G.; Rana, J.; Scholten, J.D. Inhibition of melanin production by a combination of Siberian larch and pomegranate fruit extracts. Fitoterapia 2012, 83, 989-995. [CrossRef] [PubMed]

57. Diwakar, G.; Rana, J.; Saito, L.; Vredeveld, D.; Zemaitis, D.; Scholten, J. Inhibitory effect of a novel combination of Salvia hispanica (chia) seed and Punica granatum (pomegranate) fruit extracts on melanin production. Fitoterapia 2014, 97, 164-171. [CrossRef]

58. Han, S.M.; Yeo, J.H.; Cho, Y.H.; Pak, S.C. Royal jelly reduces melanin synthesis through down-regulation of tyrosinase expression. Am. J. Chin. Med. 2011, 39, 1253-1260. [CrossRef]

59. Gilchrest, B.A.; Eller, M.S. DNA photodamage stimulates melanogenesis and other photoprotective responses. J. Investig. Dermatol. Symp. Proc. 1999, 4, 35-40. [CrossRef] [PubMed]

60. Couteau, C.; Coiffard, L. Overview of skin whitening agents: Drugs and cosmetic products. Cosmetics 2016, 3, 27. [CrossRef]

61. Katsambas, A.D.; Stratigos, A.J. Depigmenting and bleaching agents: Coping with hyperpigmentation. Clin. Dermatol. 2001, 19, 483-488. [CrossRef]

62. Arung, E.T.; Shimizu, K.; Kondo, R. Artocarpus plants as a potential source of skin whitening agents. Nat. Prod. Commun. 2011, 6, 1397-1402. [CrossRef] [PubMed]

63. Javanmardi, J.; Stushnoff, C.; Locke, E.; Vivanco, J.M. Antioxidant activity and total phenolic content of Iranian Ocimum accessions. Food Chem. 2003, 83, 547-550. [CrossRef]

64. Joubert, E.; Manley, M.; Botha, M. Evaluation of spectrophotometric methods for screening of green rooibos (Aspalathus linearis) and green honeybush (Cyclopia genistoides) extracts for high levels of bio-active compounds. Phytochem. Anal. 2008, 19, 169-178. [CrossRef]

65. Itsarasook, K.; Ingkaninan, K.; Viyoch, J. Artocarpin-enriched extract reverses collagen metabolism in UV-exposed fibroblasts. Biologia 2014, 69, 943-951. [CrossRef]

66. Ko, H.H.; Tsai, Y.T.; Yen, M.H.; Lin, C.C.; Liang, C.J.; Yang, T.H.; Lee, C.W.; Yen, F.L. Norartocarpetin from a folk medicine Artocarpus communis plays a melanogenesis inhibitor without cytotoxicity in B16F10 cell and skin irritation in mice. BMC Complement. Altern. Med. 2013, 13, 348. [CrossRef] 
67. Stratigos, A.J.; Katsambas, A.D. Optimal management of recalcitrant disorders of hyperpigmentation in dark-skinned patients. Am. J. Clin. Dermatol. 2004, 5, 161-168. [CrossRef] [PubMed]

68. Bilodeau, M.L.; Greulich, J.D.; Hullinger, R.L.; Bertolotto, C.; Ballotti, R.; Andrisani, O.M. BMP-2 stimulates tyrosinase gene expression and melanogenesis in differentiated melanocytes. Pigment Cell Res. 2001, 14, 328-336. [CrossRef] [PubMed]

69. Rodboon, T.; Puchadapirom, P.; Okada, S.; Suwannalert, P. Oxyresveratrol from Artocarpus lakoocha Roxb. Inhibit Melanogenesis in B16 Melanoma Cells through the Role of Cellular Oxidants. Walailak J. Sci. Technol. 2015, 13, 261-270.

70. Lin, V.C.; Ding, H.Y.; Kuo, S.Y.; Chin, L.W.; Wu, J.Y.; Chang, T.S. Evaluation of in vitro and in vivo depigmenting activity of raspberry ketone from rheum officinale. Int. J. Mol. 2011, 12, 4819-4835. [CrossRef]

71. Zaidi, K.U.; Ali, S.A.; Ali, A.S. Purified Mushroom Tyrosinase Induced Melanogenic Protein Expression in B16F10 Melanocytes: A Quantitative Densitometric Analysis. Open Med. Chem. J. 2018, 12, 36-47. [CrossRef]

Publisher's Note: MDPI stays neutral with regard to jurisdictional claims in published maps and institutional affiliations.

(C) 2020 by the authors. Licensee MDPI, Basel, Switzerland. This article is an open access article distributed under the terms and conditions of the Creative Commons Attribution (CC BY) license (http://creativecommons.org/licenses/by/4.0/). 